\title{
First record of Eucoilinae (Hymenoptera: Figitidae), parasitoids of African fig fly Zaprionus indianus Gupta (Diptera: Drosophilidae), in the Caatinga biome
}

\author{
Primeiro registro de Eucoilinae (Hymenoptera: Figitidae), \\ parasitoides da Mosca-africana-do-figo Zaprionus indianus Gupta \\ (Diptera: Drosophilidae), no bioma Caatinga
}

\author{
Wigna Gabriela Nunes Santos ${ }^{1}$; Elania Clementino Fernandes'; \\ Mariana Macedo Souza ${ }^{3}$; Jorge Anderson Guimarães ${ }^{4}$; Elton Lucio Araujo ${ }^{5 *}$
}

\begin{abstract}
This study records the occurrence of eucoilines (Hymenoptera: Figitidae), parasitoids of the African fig fly Zaprionus indianus Gupta (Diptera: Drosophilidae), in the Brazilian semi-arid Caatinga biome. We obtained from mango (Mangifera indica L.) and guava (Psidium guajava L.) fruits Drosophilidae pupae, which developed into Z. indianus and two species of Eucoilinae parasitoids, Dicerataspis grenadensis Ashmead and Leptopilina boulardi (Barbotin, Carlton \& Kelner-Pillaut). This is the first record of the parasitoids $D$. grenadensis and $L$. boulardi in the Caatinga biome.
\end{abstract}

Key words: Diversity. Natural enemies. Eucoilinae. Frugivorous flies. Semi-arid, Brazil.

\section{Resumo}

Este trabalho relata a ocorrência de eucoilíneos (Hymenoptera: Figitidae), parasitoides da Moscaafricana-do-figo Zaprionus indianus Gupta (Diptera: Drosophilidae), no bioma Caatinga, semiárido Brasileiro. De frutos de manga (Mangifera indica L.) e goiaba (Psidium guajava L.) foram obtidos pupários de Drosophilidae dos quais emergiram $Z$. indianus e duas espécies de parasitoides Eucoilinae, Dicerataspis grenadensis Ashmead e Leptopilina boulardi (Barbotin, Carlton \& Kelner-Pillaut). Este é o primeiro relato dos parasitoides $D$. grenadensis e L. boulardi no bioma Caatinga.

Palavras-chave: Diversidade. Inimigos naturais. Eucoilinae. Moscas frugívoras. Semiárido.

\footnotetext{
${ }^{1}$ Discente do Curso de Mestrado do Programa de Pós-Graduação em Fitotecnia, Universidade Federal Rural do Semi-Árido, UFERSA, Mossoró, RN, Brasil. E-mail: wignagabi@hotmail.com

${ }^{2}$ Discente do Curso de Doutorado do Programa de Pós-Graduação em Fitotecnia, UFERSA, Mossoró, RN, Brasil. E-mail: elania19@hotmail.com

${ }^{3}$ Discente do Curso da Graduação em Agronomia, UFERSA, Mossoró, RN, Brasil. E-mail: mari.macedo.dsouza@gmail.com

${ }^{4}$ Pesquisador Dr., Empresa Brasileira de Pesquisa Agropecuária, EMBRAPA, Centro Nacional de Pesquisa de Hortaliças, Anápolis, Brasil. E-mail: jorge.anderson@embrapa.br

${ }^{5}$ Prof. Dr., Dept ${ }^{\circ}$ de Ciências Vegetais, UFERSA, Mossoró, RN, Brasil. E-mail: elton@ufersa.edu.br

* Author for correspondence
} 
Parasitoids (Figitidae) are important natural enemies of frugivorous flies (Tephritidae, Lonchaeidae, and Drosophilidae) in the Neotropical Region (GUIMARÃES et al., 2003; NÚÑEZCAMPERO et al., 2014). Among the figitids, the subfamily Eucoilinae is the most diversified, comprising about 970 species distributed in 85 genera (BUFFINGTON, 2009; FORSHAGE et al., 2013).

In Brazil, about 60 species and 31 genera of eucoilines are known. In this group, 12 species are associated with larvae of Tephritoidea (GALLARDO et al., 2010; GUIMARÃES et al., 2003). Most of the studies about diversity and distribution of Eucoilinae are concentrated in the Southeast region of Brazil (GUIMARÃES et al., 2004); thus, there is a lack of knowledge on Eucoilinae in the other regions and biomes of Brazil.

The parasitism of Eucoilinae species helps to regulate the population of frugivorous flies, such as the African fig fly Zaprionus indianus Gupta, 1970 (Diptera: Drosophilidae), an introduced species in Brazil. This drosophilidae fly was reported for the first time in Brazil in 1999 in the State of São Paulo, infesting fruits of kaki (Diospyros kaki L.: Ebenaceae) and fig (Ficus carica L.: Moraceae) (COMMAR et al., 2012). Zaprionus indianus is a polyphagous species, and studies show that its distribution is rapidly expanding in Brazil, including the Caatinga biome (FERNANDES; ARAUJO, 2011). This biome is located in Northeastern Brazil, occupying $11 \%$ of the country, and is characterized by xerophytic vegetation and semi-arid climate (ALVES et al., 2009). This is the region where many tropical fruits are grown.

However, despite the importance of fruit production and the potential of $Z$. indianus as a pest in the Brazilian semi-arid region, not many studies have presented information on the natural enemies associated with $Z$. indianus in the Caatinga biome. Thus, this study was carried out to verify if there are Eucoilinae species associated with $Z$. indianus larvae in the Brazilian semi-arid Caatinga biome.
Although Z. indianus is not a primary invasive insect of mango (Mangifera indica L.: Anacardiaceae) and guava (Psidium guajava L.: Myrtaceae), infestation of larvae of $Z$. indianus was observed in these fruits on the ground. Thus, we collected samples of mango (32 kg/60 fruits) and guava (106 kg/1,331 fruits) from the Caatinga biome, in the municipalities of Baraúna (57'33.4"

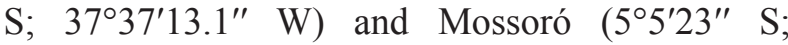
$\left.37^{\circ} 23^{\prime} 50^{\prime \prime} \mathrm{W}\right)$ in the State of Rio Grande do Norte and the municipality of Limoeiro do Norte $\left(5^{\circ} 8^{\prime} 56.6^{\prime \prime} \mathrm{S} ; 38^{\circ} 6^{\prime} 9.2^{\prime \prime} \mathrm{W}\right)$ in the State of Ceará, from May 2011 to November 2013. The collected fruits were packed in paper bags and transported to the Laboratory. In the laboratory, the fruits were counted, weighed, placed in plastic trays with a layer $(5 \mathrm{~cm})$ of vermiculite, and covered with voile cloth, to obtain the pupae of flies. The obtained pupae of Z. indianus were placed in Petri dishes covered with plastic wrap and maintained in a room at $26^{\circ} \mathrm{C}, 60 \pm 10 \% \mathrm{RH}$, and $12 \mathrm{~h}$ photophase, until the emergence of adults. The association between $Z$. indianus and its parasitoids was confirmed because in the samples with eucoilines, only $Z$. indianus emerged. The parasitoids and flies were identified following Guimarães et al. (2003) and Commar et al. (2012), respectively.

From the collected fruits, 93 pupae of $Z$. indianus were obtained, which 64 adult flies, seven Dicerataspis grenadensis Ashmead, 1986 (Hymenoptera: Figitidae: Eucoilinae) and two Leptopilina boulardi (Barbotin et al., 1979) (Hymenoptera: Figitidae: Eucoilinae) emerged. Dicerataspis and Leptopilina are commonly associated with larvae-pupae of drosophilids and are important natural enemies of dipterans (GUIMARÃES et al., 2003).

The genus Dicerataspis comprises only one species, D. grenadensis (GALLARDO et al., 2010). In Brazil, this species was reported in the States of Pará and Minas Gerais, but with no record of the host (GUIMARÃES et al., 2004). In the State of São Paulo, D. grenadensis as Dicerataspis flavipes 
was shown to be associated with $Z$. indianus in different fruit trees (GUIMARÃES et al., 2004). Leptopilina species are distributed worldwide and are always associated with drosophilid larvae (FORSHAGE et al., 2013; NOVKOVIC et al., 2011), and L. boulardi is commonly associated with Drosophila melanogaster (Meigen, 1830) (Diptera: Drosophilidae) (FLEURY et al., 2009). However, in Brazil, this species was reported to parasitize Z. indianus in the Cerrado biome in the State of Goiás (MARCHIORI et al., 2003). In addition, the occurrence of $L$. boulardi has been observed in the States of São Paulo, Rio de Janeiro, Minas Gerais, Amapá, Bahia, and Rio Grande do Norte, with no clear record of its host (GUIMARÃES et al., 2003, 2004).

Thus, this is the first study showing $D$. grenadensis and L. boulardi in the Caatinga biome. Moreover, this is the first study to show eucoilines parasitizing $Z$. indianus in the Caatinga biome. Further, D. grenadensis obtained in mango fruits in Baraúna and L. boulardi obtained in guava fruits in Mossoró and Limoeiro do Norte show new geographic distributions of these two eucoilines in Brazil.

The details presented in this study show that parasitoids Figitidae (Eucoilinae) associated with the invasive species $Z$. indianus are present in the Brazilian semi-arid Caatinga biome. This information is important because it shows the expansion and distribution records of eucoilines in Brazil, and also shows that these parasitoids can be potentially used in the integrated management of $Z$. indianus, if it reaches pest status in fruits grown in the semi-arid region. However, further studies must be conducted to improve the knowledge of the bionomics of these natural enemies and their importance in the regulation of $Z$. indianus population in the Caatinga biome.

\section{Acknowledgments}

We thank Coordenação de Aperfeiçoamento de Pessoal de Nível Superior (CAPES), for the MSc scholarship to Wigna Santos and Elania Fernandes. We also express our gratitude to Conselho Nacional de Desenvolvimento Científico e Tecnológico (CNPq) for the research grant to Elton Araujo. We thank Dr. Carlos R. Vilela for identification of Zaprionus indianus.

\section{References}

ALVES, J. J. A.; ARAÚJO, M. A.; NASCIMENTO, S. S. Degradação da Caatinga: uma investigação ecogeográfica. Revista Caatinga, Mossoró, v. 22, n. 3, p. 126-135, 2009.

BUFFINGTON, M. Description, circumscription and phylogenetics of the new tribe Zaeucoilini (Hymenoptera: Figitidae: Eucoilinae), including a description of a new genus. Systematic Entomology, Oxford, v. 34, n. 1, p. 162-187, 2009.

COMMAR, L. S.; GALEGO, L. G. C.; CERON, C. R.; CARARETO, C. M. A. Taxonomic and evolutionary analysis of Zaprionus indianus and its colonization of Paleartic and Neotropical regions. Genetics and Molecular Biology, Ribeirão Preto, v. 35, n. 2, p. 395406, 2012.

FERNANDES, D. R. R; ARAUJO, E. L. Ocorrência de Zaprionus indianus Gupta (Diptera: Drosophilidae) em frutos de juazeiro Ziziphus joazeiro Mart. (Rhamnaceae) no estado do Rio Grande do Norte. Revista Brasileira de Fruticultura, Cruz das Almas, v. 33, n. 4, p. 1356-1358, 2011.

FLEURY, F.; GILBERT, P.; RIS, N.; ALLEMAND, R. Ecology and life history evolution of frugivorous Drosophila parasitoids. In: PREVOST, G. (Ed.). Advances in parasitology: parasitoids of Drosophila. Burlington: Academic Press, 2009. p. 3-44.

FORSHAGE, M.; NORDLANDER, G.; BUFFINGTON, M. L. Eucoilinae of North America: a revised of genera and described species. Proceedings of the Entomological Society of Washington, Laurel, v. 115, n. 3, p. 225-255, 2013. 
GALLARDO, F. E.; DIAZ, N. B.; GUIMARÃES, J. A. Contribution to the systematics of Dicerataspis Ashmead, 1896 (Hymenoptera: Cynipoidea: Figitidae). Entomological News, Philadelphia, v. 121, n. 1, p. 23-30, 2010.

GUimARÃES, J. A.; GALLARDO, F. E.; DIAZ, N. B.; ZUCCHI, R. A. Eucoilinae species (Hymenoptera: Cynipoidea: Figitidae) parasitoids of fruit-infesting dipterous in Brazil: Identity, geographical distribution and host associations. Zootaxa, Auckland, v. 278, n. 1, p. 1-23, 2003.

GUIMARÃES, J. A.; SOUZA FILHO, M. F.; RAGA, A.; ZUCCHI, R. A. Levantamento e interações tritróficas de figitídeos (Hymenoptera: Eucoilinae) parasitóides de larvas frugívoras (Diptera) no Brasil. Arquivos do Instituto Biológico, São Paulo, v. 71, n. 1, p. 51-56, 2004.
MARCHIORI, C. H.; ARANTES, S. B.; PEREIRA, L. A.; SILVA FILHO, O. M.; BORGES, V. R. First record of Leptopilina boulardi Barbotin et al. (Hymenoptera: Figitidae: Eucoilinae) parasitizing of Zaprionus indianus Gupta (Diptera: Drosophilidae) in Brazil. Semina: Ciências Agrárias, Londrina, v. 24, n. 2, p. 321-324, 2003.

NOVKOVIC, B.; MITSUI, H.; SUWITO, A.; KIMURA, M. T. Taxonomy and phylogeny of Leptopilina species (Hymenoptera: Cynipoidea, Figitidae) attacking frugivorous drosophilid flies in Japan, with description of three new species. Entomological Science, Tokyo, v. 14, n. 3, p. 333-346, 2011.

NÚÑEZ-CAMPERO, R.; ALUJA, M.; RULL, J.; OVRUSKI, S. M. Comparative demography of three neotropical larval-prepupal parasitoid species associated with Anastrepha fraterculus (Diptera: Tephritidae). Biological Control, San Diego, v. 69, n. 1, p. 8-17, 2014. 